\title{
PENGARUH METODE THINK PAIRS SHARE TERHADAP HASIL BELAJAR PADA PELAJARAN EKONOMI DI `SMEA TAQWA BELITANG
}

\author{
Oleh: Andi Andriyansyah \\ andiandriyansyah77@gmail.com \\ (Program Studi Ekonomi Manajemen, FE STIE Trisna Negara)
}

\begin{abstract}
Abstrak-Tujuan penelitian ini yaitu untuk mengetahui pengaruh metode think pairs share terhadap hasil belajar siswa pada mata pelajaran ekonomi kelas $X$ di SMEA Taqwa Belitang OKU Timur. Metode penelitian yang digunakan dalam penelitian ini adalah metode eksperimen. Berdasarkan hasil penelitian yang telah dilakukan melalui ujii " $t$ " maupun uji " $F$ " sama-sama menunjukkan hasil yang sama yaitu pengaruh positif terhadap hasil belajar siswa dengan menggunakan metode thunk pair share pada mata pelajaran ekonomi materi uang di SMEA Taqwa Belitang OKU Timur. Pengaruh yang sangat kuat dalam proses belajar mengajar dengan menggunakan metode think pair share di kelas X IPS 3 (kelas eksperimen), proses belajar mengajar sangat efektif dan aktif dibanding kelas $X$ IPS 2 (kelas kontrol) yang tidak menggunakan metode think pair share.
\end{abstract}

Kata Kunci: Think Pairs Share, Hasil Belajar, Eonomi, SMEA Taqwa Belitang

Abstract-The research objective was to determine the effect of the think pairs share method on student learning outcomes in class X economics at SMEA Taqwa Belitang OKU Timur. The research method used in this research is the experimental method. Based on the results of research that has been carried out through the " $t$ " test and the " $F$ " test, both show the same results, namely a positive effect on student learning outcomes using the thunk pair share method on the subject of money material economics at SMEA Taqwa Belitang OKU Timur. A very strong influence in the teaching and learning process using the think pair share method in class X IPS 3 (experimental class), the teaching and learning process is very effective and active compared to class X IPS 2 (control class) which does not use the think pair share method.

Keywords: Think Pair Share, Learning Outcomes, Economics, Taqwa Belitang High School

\section{PENDAHULUAN}

Pendidikan merupakan faktor penentu kualitas suatu bangsa. Pendidikan dalam kehidupan manusia merupakan kebutuhan mutlak yang harus dipenuhi sepanjang hayat. Untuk meningkatkan kualitas pendidikan nasional, berbagai upaya yang dapat dilakukan adalah pembaruan kurikulum, peningkatan kualitas tenaga pendidik, peningkatan sarana dan prasarana pendidikan, penataan manajemen pendidikan serta 
penerapan teknologi informasi dalam pendidikan. Sekolah merupakan sarana belajar anak yang dididik untuk menjadi individu yang berpotensi di masyarakat. Setiap individu yang dididik memiliki karakteristik yang berbeda-beda. Ada anak yang belajar melalui proses yang mudah, cepat diterimanya tapi tidak jarang anak yang mengalami kesulitan dalam belajar. Di era globalisasi saat ini guru adalah fasilitator bagi siswa yang berperan sebagai tenaga pendidik dalam proses belajar mengajar. Guru berperan pentinguntuk menciptakan suasana belajar mengajar yang efektif, sedangkan siswa dituntut untuk adanya semangat dan dorongan untuk aktif dalam proses belajar mengajar. Sehingga keberhasilan belajar dalam bidang kognitif, psikomotorik, dan afektif dapat tercapai. Guru sebagai tenaga pendidik perlu mempersiapkan strategi belajar mengajar untuk membantu kendala siswa dalam belajar.

Ekonomi merupakan salah satu cabang dari Ilmu Pendidikan Sosial di sekolah menengah atas yang diperlukan dalam pendidikan. Pelajaran ekonomi berfungsi untuk melatih siswa dalam memecahkan masalah ekonomi yang sedang terjadi di lingkungan masyarakat agar dapat menciptakan kehidupan yang sejahtera. Pelajaran ekonomi adalah ilmu yang membekali siswa untuk dapat memenuhi kebutuhan hidupnya dengan kegiatan produktif, distribusi dan konsumsi untuk mencapai kemakmuran. Ilmu ekonomi ini terus berkembang, maka dalam mempelajari ilmu ekonomi sangat diperlukan cara pembelajaran yang tepat dengan tujuan agar siswa dapat memahami, menguasai, menerapkan dan mengembangkan ilmu ekonomi ini dalam kehidupan sehari-hari.

Oleh karena itu, pengajarannya perlu diperhatikan karena masih banyak siswa yang beranggapan bahwa pelajaran ekonomi sukar dipahami dan membosankan. Dalam pelaksanaannya, guru harus dapat memilih metode pembelajaran yang sesuai dengan materi yang akan diajarkan, supaya siswa terhindar dari kejenuhan dan kebosanan dalam proses belajar mengajar. Sehingga, tercipta kondisi atau suasana belajar yang interaktif, efektif dan efisien.

$\begin{array}{rlr}\text { Banyak } & \text { faktor } & \begin{array}{r}\text { yang } \\ \text { menyebabkan }\end{array} \\ \text { anak } & \text { kurang }\end{array}$
menyenangi apa yang ia pelajari di sekolah salah satunya mata pelajaran ekonomi. Hal yang menyebabkannya itu karena adanya pola yang bersifat monoton dalam menyampaikan materi. Dalam proses belajar mengajar guru memiliki peranan penting dalam menentukan kualitas pembelajaran yang dilaksanakan, guru harus bisa memikirkan dan membuat perencanaan proses belajar secara maksimal sehingga dapat meningkatkan hasil belajar siswa.

Pelaksanaan pengajaran yang baik sangat dipengaruhi oleh 
perencanaan dan strategi pembelajaran yang baik pula. Pengaruh dalam penggunaan staregi pembelajaran dapat memperlihatkan baik buruk pada motivasi dan aktivitas belajar pesertadidik pada materi tersebut, hal ini juga dapat berdampak kurang baik terhadap hasil belajar peserta didik tersebut, sebaliknya apabila pendidik bias menggunakan strategi belajar yang baik dalam proses pembelajaran pada akhirnya akan berpengaruh atas motivasi dan berhasil dalam pembelajaranya (Lestari, 2018:178).

Metode pembelajaran juga dapat menentukan kegiatan belajar siswa dan hasil belajar siswa, maka dalam menentukan metode mengajar guru perlu memperhatikan kemampuan siswa dan harus sesuai dengan materi yang akan disampaikan, serta kemampuan guru itu sendiri dalam menyampaikan metode pembelajaran tersebut. Belajar bisa menyenangkan bila dilakukan dengan metode yang mudah diterima siswa namun tidak membosankan. Salah satu metode belajar yang menyenangkan itu dapat menggunakan metode think pairs share, karena metode ini bisa mengoptimalkan partisipasi siswa dan memungkinkan siswa untuk bekerja sendiri dan bekerja sama dengan orang lain.

Berdasarkan informasi awal sebelum penelitian, yang peneliti peroleh pada SMEA Taqwa Belitang OKU Timur diketahui cara mengajar pada mata pelajaran ekonomi masih menggunakan metode tradisional yaitu metode ceramah. Dimana peran guru sangat dominan sehingga proses pembelajaran masih berpusat pada guru, sementara siswa sangat pasif karena siswa hanya mendengarkan informasi yang diberikan oleh guru. Kegiatan ini mengakibatkan siswa yang kurang aktif dan kurang termotivasi dalam belajar ekonomi sehingga siswa kurang memahami materi yang telah disampaikan oleh guru, hasil belajar siswa pun kurang maksimal, sehingga kriteria ketuntasan maksimal yang telah ditetapkan belum sepenuhnya tercapai.

Untuk menindak lanjuti masalah di atas maka diperlukannya suatu usaha oleh guru guna memperbaiki kualitas pembelajaran, salah satunya yaitu dengan cara menggunakan pembelajaran bervariasi yang sesuai dengan materi dan tujuan yang ingin dicapai. Salah satu cara yang dapat digunakan dalam proses belajar mengajar adalah dengan menggunakan metode think pair share.

Metode think pairs share ini merupakan metode yang sederhana namun bermanfaat, seperti namanya : "Thinking (berfikir)", siswa diberi kesempatan untuk mencari jawaban atas pertanyaan yang telah diberikan oleh guru, "pairing (berpasangan), siswa bertukar fikiran dengan teman sebangkunya, "sharing (berbagi)", siswa menjelaskan jawaban yang 
telah mereka sepakati di depan kelas. Dengan menggunakan metode think pairs share ini siswa bisa fokus pada inti materi dan mudah mengingat materi yang dipelajari.

Metode pembelajaran adalah cara sistematis dalam bentuk konkret berupa langkah-langkah untuk mengefektifkan pelaksanaan suatu pembelajaran. Pada dasarnya setiap guru menginginkan agar materi pelajaran yang disampaikan kepada anak didiknya dapat dipahami secara tuntas. Dengan menggunakan metode mengajar yang tepat dapat meningkatkan motivasi siswa untuk belajar, sehingga memberi kemudahan bagi siswa untuk mencapai hasil belajar yang baik.

"Metode mengajar adalah suatu jalan atau cara yang harus dilalui didalam mengajar", (Slameto, 2010:65). Menurut Yulaini dkk (2020:22) "mengemukakan bahwa metode pembelajaran adalah suatu cara atau upaya yang dilakukan oleh para pendidik agar proses belajar mengajar pada siswa tercapai sesuai tujuan". Berdasarkan penjelasan tersebut, maka dalam penggunaan metode mengajar yang tepat dapat merangsang rasa ingin tahu siswa, sehingga dapat membantu guru dalam mencapai tujuan pengajaran dan mampu meningkatkan hasil belajar siswa.

Dari beberapa pendapat di atas, dapat disimpulkan bahwa metode mengajar adalah suatu cara yang digunakan guru dalam mengajar yang mempengaruhi belajar siswa agar tercapai tujuan pembelajaran.

Faktor yang Mempengaruhi Pemilihan Metode ada beberapa faktor yang mempengaruhi pemilihan dan penentuan metode yaitu :

a. Anak didik

Anak didik adalah manusia berpotensi yang menghajatkan pendidikan. Secara intelektual, anak didik selalu menunjukkan perbedaan. Hal ini terlihat dari cepatnya tanggapan anak didik terhadap rangsangan yang diberikan dalam kegiatan belajar mengajar, dan lambatnya tanggapan anak didik terhadap rangsangan yang diberikan guru.

b. Tujuan

Tujuan adalah sasaran yang dituju dari setiap kegiatan belajar mengajar. Tujuan dalam penelitian dan pengajaran berbgaibagai jenis dan fungsinya. Secara hierarki tujuan itu bergerak dari yang rendah hingga yang tinggi, yaitu tujuan intruksional atau tujuan pembelajaran, tujuan kurikuler atau tujuan kurikulum, tujuan institusional, dan tujuan pendidikan nasional.

c. Situasi

Situasi kegiatan belajar mengajar yang guru ciptakan tidak selamanya sama dari hari ke hari. Pada suatu waktu boleh jadi guru ingin menciptakan situasi belajar mengajar di alam terbuka, yaitu di luar ruang sekolah. 
d. Fasilitas

Fasilitas merupakan hal yang mempengaruhi pemilihan dan penentuan metode mengajar. Fasilitas adalah kelengkapan yang menunjang belajar anak didik di sekolah. Lengkap tidaknya fasilitas belajar akan mempengaruhi pemilihan metode mengajar.

e. Guru

Setiap guru mempunyai kepribadian yang berbeda. Seorang guru misalnya kurang suka berbicara, tetapi seorang guru yang lain suka berbicara. Latar belakang pendidikan guru diakui mempengaruhi kompetensi. Kurangnya penguasaan terhadap berbagai jenis metode menjadi kendala dalam memilih dan menentukan metode.

Banyak metode pembelajaran yang digunakan oleh guru dalam proses belajar mengajar. Ada beberapa metode pembelajaran, diantaranya adalah :

a. Student Teams Achievment Division (STAD)

Student Teams Achievment Division (STAD) adalah metode pembelajaran kooperatif untuk pengelompokkan kemampuan campur yang melibatkan pengakuan tim dan tanggung jawab kelompok untuk pembelajaran individu anggota. Keanggotaan campuran menurut tingkat prestasi, jenis kelamin, dan suku.

b. Think Pairs Share (TPS)

Dalam metode ini guru menyajikan materi dengan memberikan persoalan kepada siswa dan siswa bekerja kelompok dengan berpasangan sebangku-sebangku, kemudian mempresentasikan hasil kelompoknya, selanjutnnya guru mengadakan kuis individual, membuat skor perkembangan tiap siswa, mengumumkan hasil kuis dan memberikan penghargaan.

c. Teams Games Tournament (TGT)

Metode TGT ( Teams Games Tournament ) yaitu metode pembelajaran dalam bentuk perbandingan (tournament) antara kelompok yang satu dengan yang lain.

d. Numbered Head Together (NHT) Metode NHT (Numbered Head Together) merupakan jenis pembelajaran kooperatif yang dirancang untuk mempengaruhi pola interaksi siswa dan sebagai alternative terhadap struktur kelas tradisional.

e. Tipe Jigsaw

Merupakan metode pembelajaran dimana siswa ditempatkan ke dalam tim beranggota enam orang untuk mempelajari materi akademik yang telah dipecah menjadi bagian-bagian untuk tiap anggota.

f. GI (Group Investigation) 
Metode GI merupakan pembelajaran yang melibatkan kelompok kecil dimana siswa bekerja menggunakan perencanaan, proyek, dan diskusi kelompok, dan kemudian mempresentasikan kedepan kelas.

g. CTL (Contextual Teaching and Learning)

Pembelajaran kontekstual adalah pembelajaran yang dimulai dengan sajian atau tanya jawab lisan (ramah, terbuka, negosiasi) yang terkait dengan dunia nyata kehidupan siswa (daily life modeling), sehingga akan terasa manfaat dari materi yang disajikan, motivasi belajar muncul, dunia pikiran siswa menjadi konkret, dan suasana menjadi kondusif, nyaman dan menyenangkan.

h. PBI (Problem Based Instuction)

PBI adalah proses pembelajaran yang titik awal pembelajaran berdasarkan masalah dalam kehidupan nyata lalu dari masalah ini siswa dirangsang untuk mempelajari masalah berdasarkan pengetahuan dan pengalaman yang telah mereka punyai sebelumnya (prior knowledge) sehingga dari prior knoeladge ini akan terbentuk pengetahuan dan pengalaman baru.

i. Problem Posing

Problem Posing adalah pemecahan masalah dengan melalui elaborasi, yaitu merumuskan kembali masalah menjadi bagian-bagian yang lebih simple sehingga dipahami.

j. TS-TS (Two Stay-Two Stray)

TS-TS adalah dengan cara siswa berbagi pengetahuan dan pengalaman dengan kelompok lain.

Dalam penelitian ini, peneliti memilih metode think pair share untuk penelitiannya dengan tujuan dapat membantu guru dalam proses pembelajaran guna mencapai tujuan pembelajaran yang sudah ditetapkan. Metode pembelajaran ini memiliki prosedur ditetapkan secara ekplisit memberikan waktu lebih banyak kepada siswa untuk memikirkan secara mendalam tentang apa yang telah dijelaskan atau dialami (berfikir, menjawab, dan saling membantu satu sama lain).

Dari sumber lain Think Pair Share merupakan tipe model cooverative learning. Dari berbagai macam model-model cooperative learning di atas, model cooperative learning tipe think pair share dianggap sebagai model pembelajaran yang dapat membuat siswa aktif dalam pembelajaran (Masnunah, 2018:238).

Pengertian Think Pair ShareThink Pair Share merupakan salah satu tipe dari metode pembelajaran kooperatif. "Think Pair Share dikembangkan oleh Frank Lyman et.al, dari Universitas Maryland pada tahun 1985", (Pramawati, 2005). Think Pair 
Share berkembang dari penelitian belajar kooperatif dan waktu tunggu. Dengan asumsi bahwa semua resitasi atau diskusi membutuhkan pengaturan untuk mengendalikan kelas secara keseluruhan, dan prosedur yang digunakan dalam Think Pair Share dapat memberi siswa lebih banyak waktu berpikir, untuk merespon dan saling membantu..

Melalui kegiatan diskusi ini, siswa diharapkan mampu saling membantu satu sama lainnya sehingga menghasilkan efek positif terhadap peningkatan respon siswa. Guru hanya melengkapi penyajian singkat atau membaca tugas, atau situasi yang menjadi tanda tanya. Guru menginginkan siswa mempertimbangkan lebih banyak apa yang dijelaskan dan dialami. Guru memilih menggunakan Think Pair Share untuk membandingkan tanya jawab kelompok secara keseluruhan.

Kegunaan Think Pair Share Menurut Miftahul Huda (2011:6) "metode Think Pairs Share dapat diterapkan untuk semua mata pelajaran dan tingkatan kelas". Kegunaan metode Think Pairs Share antara lain:

a. Memungkinkan siswa untuk bekerja sendiri dan bekerja sama dengan orang lain.

b. Mengoptimalkan partisipasi siswa.

c. Memberi kesempatan sedikitnya delapan kali lebih banyak kepada setiap siswa untuk menunjukkan partisipasi mereka kepada orang lain.
Kelebihan dan Kelemahan Metode Think Pair ShareKelebihan-kelebihan dari metode think pair share yaitu :

a. Memberi siswa waktu lebih banyak untuk berfikir, menjawab, dan saling membantu satu sama lain.

b. Interaksi lebih mudah.

c. Lebih mudah dan cepat membentuk kelompoknya.

d. Seorang siswa juga dapat belajar dari siswa lain serta saling menyampaikan idenya untuk didiskusikan sebelum disampaikan di depan kelas.

e. Dapat memperbaiki rasa percaya diri dan semua siswa diberi kesempatan untuk berpartisipasi dalam kelas.

f. Siswa dapat mengembangkan keterampilan berfikir dan menjawab dalam komunikasi antara satu dengan yang lain, serta bekerja saling membantu dalam kelompok kecil.

g. Siswa secara langsung dapat memecahkan masalah.

h. Siswa akan lebih aktif dalam pembelajaran karena menyelesaikan tugasnya dalam kelompok

i. Siswa memperoleh kesempatan untuk mempersentasikan hasil diskusinya dengan seluruh siswa.

Kelemahan Metode Think Pair Share-Kelemahan-kelemahan dari metode think pair share yaitu:

a. Membutuhkan koordinasi secara bersamaan dari berbagai aktivitas. 
b. Membutuhkan perhatian khusus dalam penggunaan ruangan kelas.

c. Banyak kelompok yang melapor dan perlu dimonitor.

d. Lebih sedikit ide yang muncul.

e. Jika ada perselisihan, tidak ada penengah.

f. Menggantungkan pada pasangan.

g. Jumlah kelompok yang terbentuk banyak.

h. Metode think pair share masih jarang digunakan

\section{Langkah-Langkah Metode}

Think Pairs Share-Langkah-langkah yang digunakan oleh guru dalam proses pembelajaran. Langkahlangkah metode think pairs share yaitu :

a. Guru menyampaikan topik inti materi dan kompetensi yang ingin dicapai

b. Siswa diminta untuk berfikir tentang materi/permasalahan yang disampaikan guru secara individual

c. Siswa diminta berpasangan dengan teman sebelahnya (kelompok 2 orang) dan mengutarakan hasil pemikiran masing-masing tentang topiknya tadi

d. Guru memimpin pleno kecil diskusi, tiap kelompok pasangan mengemukakan hasil diskusinya untuk berbagi jawaban (share) dengan seluruh siswa di kelas

e. Berawal dari kegiatan tersebut mengarahkan pembicaraan pada pokok permasalahan dan menambah materi yang belum diungkapkan para siswa

f. Guru member kesimpulan

g. Penutup

Hasil Belajar-Hasil belajar dapat dijelaskan dengan memahami dua istilah kata yang membentuknya, yaitu "hasil" dan "belajar". Pengertian hasil menunjuk pada suatu perolehan akibat dilakukannya suatu aktivitas atau proses yang mengakibatkan berubahnya input secara fungsional. Belajar dilakukan untuk mengusahakan adanya perubahan perilaku pada individu yang belajar. Perubahan perilaku itu merupakan perolehan yang menjadi hasil belajar.

"Hasil belajar adalah perubahan yang mengakibatkan manusia berubah dalam sikap dan tingkah lakunya", (Winkel,2010:45). Purwanto (2010:46) "mengatakan hasil belajar merupakan pencapaian tujuan pendidikan pada siswa yang mengikuti proses belajara mengajar". Sudjana (2010:22) "mengatakan bahwa hasil belajar adalah kemampuan-kemampuan yang dimiliki oleh siswa setelah menerima pengalamaan belajarnya".

Di dalam proses belajar mengajar pasti mempunyai tujuan yang ingin dicapai dan telah ditetapkan sebelumnya. Tujuan tersebut adalah hasil belajar, yang tidak mudah dicapai dengan baik jika tidak memperhatikan strategi, metode serta faktor yang diperlukan 
dalam proses belajar mengajar. Pencapaian tujuan pembelajaran merupakan hasil dari kegiatan belajar mengajar.

Dari pengertian di atas, dapat disimpulkan bahwa hasil belajar merupakan suatu hasil kemampuan yang dicapai atau diperoleh siswa dari proses belajar, baik itu pengetahuan maupun keterampilan yang ditunjukan dengan prestasi belajar siswa itu sendiri.

Dengan demikian hasil belajar yang maksimal dapat dicapai oleh peserta didik, maka saat ini diperlukan banyak dikembangkan model pembelajaran yang berguna dan bertujuan untuk mendorong siswa dalam meningkatkan keaktifan setiap siswa didalam proses pembelajaran (Putri dkk, 2019:78)

Dalam penelitian ini, hasil belajar diperoleh oleh siswa dari hasil evaluasi yang diberikan oleh guru kepada siswa berupa soal tes. Evaluasi ini diberikan setelah proses pembelajaran selesai guna mengetahui seberapa jauh siswa menguasai bahan yang sudah diajarkan. Proses penilaian terhadap hasil belajar dapat memberikan informasi kepada guru tentang kemajuan siswa dalam upaya mencapai tujuan-tujuan belajarnya melalui kegiatan pembelajaran.

Pengertian Mata Pelajaran Ekonomi-Mata pelajaran ekonomi merupakan cabang dari ilmu pengetahuan sosial yang mempelajari berbagai perilaku pelaku ekonomi terhadap keputusan-keputusan ekonomi yang dibuat. Ekonomi adalah sebuah ilmu yang mempelajari tentang bagaimana manusia mencukupi kebutuhan hidupnya. Menurut kurikulum 2006 "dijelaskan bahwa mata pelajaran ekonomi adalah mata pelajaran yang mempelajari tentang ilmu ekonomi, tingkat kebutuhan manusia”. Kata ekonomi berasal dari bahasa Yunani yaitu Oikonomia. Kata ini terdiri dari dua kata yaitu Oikos dan Nomos. Oikos yang artinya rumah tangga dan Nomos yang artinya peraturan. Jadi ekonomi artinya peraturan rumah tangga.

Dari uraian di atas, maka peneliti terdorong untuk melakukan penelitian dengan judul :"Pengaruh Metode Think Pairs Share Terhadap Hasil Belajar Siswa Pada Mata Pelajaran Ekonomi di SMEA Taqwa Belitang OKU TIMUR".

\section{METODE PENELITIAN}

Ada berbagai cara menentukan metode penelitian, menurut Nazir (2010:73) mengatakan "bahwa metode penelitian dapat dilihat dari : 1) cara untuk mengumpulkan data, 2) berdasarkan prosedur penelitian dan atau keduanya". Sedangkan Sugiyono (2010:6-9) mengatakan bahwa "metode penelitian dapat dilihat dari : 1) jenis penelitian, 2) bidang penelitian, 3) berdasarkan tujuan dan tingkat kealamiahan. Metode bentuk tersebut sebagian dari berbagai jenis penelitian". Arikunto 
(2010:203) mengatakan bahwa "Metode penelitian adalah cara yang digunakan oleh peneliti dalam mengumpulkan data penelitiannya". Penelitian ini berhubungan dengan pendidikan maka definisi yang diambil adalah penelitian pendidikan. Sugiyono (2012:6) mengatakan bahwa "Metode penelitian pendidikan adalah sebagai cara ilmiah untuk mendapatkan data yang valid dengan tujuan dapat ditemukan, dikembangkan, dan dibuktikan, suatu pengetahuan tertentu sehingga pada gilirannya dapat digunakan untuk memahami, memecahkan, dan mengantisipasi masalah dalam bidang pendidikan".

Metode penelitian yang digunakan dalam penelitian ini adalah metode eksperimen. Dengan metode ini peneliti ingin mengetahui pengaruh metode think pair share terhadap hasil belajar siswa kelas $\mathrm{X}$ pada mata pelajaran ekonomi di SMEA Taqwa Belitang OKU Timur.. Langkah-langkah yang digunakan dengan menggunakan metode ini yaitu :

a. Berfikir (think) : guru mengajukan suatu pertanyaan atau masalah yang dikaitkan dengan pelajaran dan meminta siswa menggunakan waktu beberapa menit untuk berfikir sendiri mengenai jawaban atas pertanyaan atau masalah tersebut.

b. Berpasangan (pair) : selanjutnya guru meminta siswa untuk berpasangan dan mendiskusikan apa yang mereka peroleh Interaksi selama waktu yang disediakan dapat menyatukan jawaban dari pertanyaan tersebut atau menyatukan gagasan bila suatu masalah khusus yang diidentifikasi.

c. Berbagi (share) : pada langkah akhir, guru meminta pasanganpasangan untuk berbagi dengan keseluruhan siswa didepan kelas atas jawaban yang telah mereka sepakati bersama.

\section{Teknik Pengumpulan Data}

\section{Teknik Dokumentasi}

"Dokumentasi adalah ditujukan untuk memperoleh data langsung dari tempat penelitian, meliputi buku-buku yang relevan, peraturanperaturan, laporan kegiatan, fotofoto, film dokumenter, data yang relevan untuk penelitian", (Riduwan, 2010:77). Menurut Arikunto (2010:274) "Teknik dokumentasi adalah mencari hal-hal atau variabel yang berupa catatan, transkrip, buku, surat kabar, majalah, prasasti, notulen, rapat, lengger, agenda, dan sebagainya".

Dalam hal ini dokumentasi digunakan hanya untuk mengetahui keadaan sekolah, jumlah siswa dan jumlah guru yang ada di SMEA Taqwa Belitang OKU Timur.

\section{Teknik Observasi}

"Observasi adalah metode atau cara-cara menganalisis dan mengadakan pencatatan secara 
sistematis mengenai tngkah laku dengan melihat atau mengamati individu atau kelompok", (Arikunto,2010:149). Riduwan (2010:76) mengatakan "Observasi yaitu melakukan pengamatan langsung ke objek penelitian untuk melihat dari dekat kegiatan yang dilakukan".

Obseravsi digunakan untuk mengetahui keaktifan belajar siswa di dalam kelas saat proses belajar mengajar berlangsung. Keaktifan siswa yang diobservasi meliputi tiga indikator, dan masing-masing indikator terdiri dari tiga deskriptor. Kisi-kisi observasi sebagai berikut :

\section{Teknik Tes}

"Tes adalah serangkaian pertanyaan atau latihan yang digunakan yang digunakan untuk mengukur keterampilan, pengetahuan, intelegensi, kemampuan, atau bakat, yang dimiliki oleh individu atau kelompok", (Riduan,2011:76).

"Tes adalah merupakan alat atau prosedur yang digunakan untuk mengetahui atau mengukur sesuatu dalam suasana, dengan cara dan aturan-aturan yang sudah ditentukan", (Arikunto,2010:53).

Tes dalam penelitian ini bertujuan untuk mengetahui hasil belajar siswa kelas $\mathrm{X}$ pada mata pelajaran ekonomi materi Uang. Tes yang diberikan kepada siswa dalam bentuk pilihan ganda yang terdiri dari 20 butir soal, dimana obsen dari setiap jawaban ini terdiri dari obsen yaitu a, b, c, d, dam e. Setiap pilihan ganda diberi nilai 5 untuk jawaban benar dan diberi nilai 0 untuk jawaban yang salah, sehingga untuk 20 soal yang benar akan mendapatkan angka 100.

\section{Teknik Uji Coba Instrumen}

Uji coba instrumen dalam penelitian ini adalah uji coba soal tes untuk mengetahui validitas butir tes dan reliabilitas soal (tes).

\section{HASIL DAN PEMBAHASAN Hasil}

Pada kelas eksperimen ini peneliti melakukan proses belajar mengajar dengan menggunakan metode Think Pair Share. Proses belajar mengajar yang dilakukan peneliti di kelas eksperimen sebanyak 3 kali pertemuan dengan 2 RPP. Untuk RPP pada saat penelitian di kelas eksperimen dapat dilihat pada lampiran.

Dalam pelaksanaan penelitian dengan menggunakan metode Think Pair Share pada mata pelajaran ekonomi dengan materi uang di SMEA Taqwa Belitang OKU Timur kelas X IPS 3. Peneliti terlebih dahulu memberitahukan tentang pelaksanaan pembelajaran dengan menggunakan metode Think Pair Share: guru membentuk pasangan bagi setiap siswa, dimana pasangan tersebut adalah teman sebangkunya. Guru menjelaskan materi pembelajaran lalu memberikan 
permasalahan pada siswa. Mengendalikan jalannya pembelajaran dengan menggunakan metode Think Pair Share.

Langkah-langkah pelaksanaan pembelajaran dengan menggunakan metode think pair share yang peneliti lakukan di kelas eksperimen yaitu pada kelas X IPS 3 adalah: Pertemuan pertama yang dilakukan pada tanggal 10 April 2020 materi pokok mendeskripsikan pengertian uang, mengidentifikasi fungsi uang, dan mendeskripsikan nilai uang. Agar siswa bisa melaksanakan metode think pair share, guru menjelaskan materi pembelajaran lalu memberikan permasalahan kepada siswa kemudian siswa diminta untuk berfikir (think) dan bertukar pendapat (pair) dengan teman sebangkunya, setelah didiskusikan dengan teman sebangku, mereka mempersentasikan (share) hasil diskusinya kedepan kelas dan siswa lain memberi tanggapan terhadap hasil diskusi tersebut.

Pertemuan kedua yang dilakukan pada tanggal 24 April 2020 materi pokok mengidentifikasi jenis-jenis uang, mendeskripsikan permintaan dan penawaran uang. Guru menjelaskan materi pembelajaran lalu memberikan permasalahan kepada siswa kemudian siswa diminta untuk berfikir (think) dan bertukar pendapat (pair) dengan teman sebangkunya, setelah didiskusikan dengan teman sebangku, mereka mempersentasikan (share) hasil diskusinya kedepan kelas dan siswa lain memberi tanggapan terhadap hasil diskusi tersebut. Setelah pembelajaran selesai guru menyiapkan beberapa soal dan siswa diminta untuk menjawab soal tersebut, dari jawaban-jawaban siswa hasil belajar dapat dikategorikan baik.

Pertemuan ketiga yang dilakukan pada tanggal 1 Mei 2020 peneliti memberikan evaluasi melalui tes tertulis berbentuk pilihan ganda yang berjumlah 20 soal. Soal, kunci jawaban, penskoran, lembar jawaban siswa, dapat dilihat pada lampiran.

\section{Deskripsi Pelaksanaan Penelitian Pada Kelas Kontrol}

Pada kelas kontrol ini peneliti melakukan proses belajar mengajar dengan menggunakan metode ceramah dan tanya jawab. Proses belajar mengajar yang dilakukan peneliti di kelas kontrol sebanyak 3 kali pertemuan dengan 2 RPP. Untuk RPP pada saat penelitian di kelas kontrol dapat dilihat pada lampiran.

Langkah-langkah elaksanaan pembelajaran dengan menggunakan metode ceramah dan tanya jawab yang peneliti lakukan di kelas kontrol yaitu pada kelas X IPS 2 adalah :

Pertemuan pertama yang dilakukan pada tanggal 27 April 2020 materi pokok mendeskripsikan pengertian uang, mengidentifikasi fungsi uang, dan mendeskripsikan nilai uang. 
Guru menjelaskan materi dengan menggunakan metode ceramah, dan melalui metode tanya jawab siswa diberi kesempatan untuk bertanya mengenai materi pembelajaran yang belum dipahaminya dan guru memberikan penjelasan tentang materi yang ditanyakan siswa.

Pertemuan kedua yang dilakukan pada tanggal 28 April 2020, guru menjelaskan materi sebelumnya kemudian menjelaskan materi selanjutnya dengan metode ceramah yaitu mengenai materi pokok mengidentifikasi jenis-jenis uang, mendeskripsikan permintaan dan penawaran uang. kemudian dengan metode tanya jawab siswa diberi kesempatan untuk bertanya mengenai materi pembelajaran yang belum dipahaminya dan guru memberikan penjelasan tentang materi yang ditanyakan siswa.

Pertemuan ketiga yang dilakukan pada tanggal 1 Mei 2020 peneliti memberikan evaluasi melalui tes tertulis berbentuk pilihan ganda yang berjumlah 20 soal. Soal, kunci jawaban, penskoran, lembar jawaban siswa, dapat dilihat pada lampiran.

\section{Deskripsi Hasil Belajar}

Hasil belajar diperoleh dari hasil tes yang diberikan kepada siswa kelas eksperimen maupun kelas kontrol setelah pembelajaran selesai. Dalam hal ini kelompok eksperimen adalah kelas yang proses belajar mengajarnya menggunakan metode Think Pair Share dalam pembelajaran ekonomi dengan materi uang.

\section{a. Deskripsi Hasil Belajar Siswa} Kelas Eksperimen

Hasil belajar siswa sampel kelas eksperimen sebanyak 34 siswa. Nilai tertinggi yaitu 100 ; nilai terendah 60 ; rata-rata hasil belajar siswa sebesar 81,92 dengan distribusi sebagai berikut:

\section{b. Deskripsi Hasil Belajar Siswa Kelas Kontrol \\ Hasil belajar siswa sampel} kelas eksperimen sebanyak 34 siswa. Nilai tertinggi yaitu 100 ; nilai terendah 60 ; rata-rata hasil belajar siswa sebesar 81,92 dengan distribusi sebagai berikut :

\section{Analisis Data Observasi}

Obseravsi digunakan untuk mengetahui keaktifan belajar siswa di dalam kelas saat proses belajar mengajar berlangsung.

Analisa data observasi ditujukan untuk mengetahui keaktifan siswa belajar dalam mata pelajaran ekonomi pada materi uang.

\section{Analisis Data Tes \\ Analisis Data Kelas Eksperimen}

Untuk melihat analisis keberhasilan siswa dalam menjawab soal tes secara lebih jelas dapat dilihat pada tabel berikut : 
Tabel 1. Kategori dan Persentase Hasil Belajar Kelas Eksperimen

\begin{tabular}{|c|c|c|c|c|}
\hline No & Tingkat Penguasaan & Kategori & Frekuensi & Persentase \\
\hline 1 & $86-100$ & Baik Sekali & 8 & $23 \%$ \\
2 & $71-85$ & Baik & 22 & $65 \%$ \\
3 & $56-70$ & Cukup & 4 & $12 \%$ \\
4 & $41-55$ & Rendah & - & - \\
5 & $\leq 40$ & Sangat Rendah & - & - \\
& Jumlah & & 34 & $100 \%$ \\
\hline
\end{tabular}

Sumber: Diolah dari hasil penelitian, 2020

Dari tabel di atas dapat diketahui sebagian besar $65 \%$ siswa memperoleh nilai pada kategori baik, sedangkan yang memperoleh nilai pada kategori baik sekali sebesar $23 \%$ dan yang memperoleh nilai pada kategoti cukup sebesar $12 \%$, dan tidak ada siswa yang memperoleh nilai pada kategori rendah dan sangat rendah.

\section{Analisia Data Tes Kelas Kontrol}

Untuk melihat keberhasilan siswa dalam menjawab soal tes secara lebih jelas dapat dilihat pada tabel berikut :

Tabel 2. Kategori dan Persentase Hasil Belajar Kelas Kontrol

\begin{tabular}{|c|c|c|c|c|}
\hline No & $\begin{array}{c}\text { Tingkat } \\
\text { Penguasaan }\end{array}$ & Kategori & Frekuensi & Persentase \\
\hline 1 & $86-100$ & Baik & - & - \\
2 & $71-85$ & Sekali & 3 & $9 \%$ \\
3 & $56-70$ & Baik & 28 & $82 \%$ \\
4 & $41-55$ & Cukup & 3 & $9 \%$ \\
5 & $\leq 40$ & Rendah & - & - \\
& & Sangat & & \\
& & Rendah & & $100 \%$ \\
\hline
\end{tabular}

Sumber: Diolah dari hasil penelitian, 2020

Dengan melihat tabel hasil belajar kelas kontrol siswa yang mendapat nilai baik sekali tidak ada, siswa yang mendapat nilai baik ada 3 orang persentasenya $9 \%$, untuk siswa yang mendapat nilai cukup ada 28 orang persentasenya $82 \%$, sedangkan siswa yang mendapat nilai rendah ada 3 orang persentasenya 9\%. Jadi dapat disimpulkan bahwa kelas kontrol rata-rata mendapatkan nilai dengan kategori cukup.

Dari tabulasi data kelas eksperimen dan kelas kontrol didapat bahwa nilai kelas eksperimen lebih besar daripada nilai kelas kontrol, 
dimana kelas eksperimen mendapat $65 \%$ dengan kategori "Baik" dan kelas kontrol $82 \%$ dengan kategori "Cukup".

\section{Pembahasan}

Berdasarkan hasil analisis diatas, maka dapat diketahui hasil observasi keaktifan siswa dan hasil belajar siswa pada kelas eksperimen dan kelas kontrol. Berdasarkan deskripsi observasi pada kelas eksperimen yang menggunakan metode Think Pair Share diperoleh skor terbesar yaitu $67,65 \%$ pada kriteria "sangat aktif", sedangkan pada kelas kontrol yang tidak mengunakan metode Think Pair Share diperoleh skor terbesar yaitu $67,65 \%$ pada kriteria "cukup aktif". Nilai rata-rata keaktifan siswa pada kelas eksperimen yaitu $84,31 \%$ pada kriteria "sangat aktif", sedangkan nilai rata-rata keaktifan siswa pada kelas kontrol yaitu 60,04 \% pada kriteria "cukup aktif".

Berdasarkan deskripsi hasil belajar pada kelas eksperimen yang menggunakan metode Think Pair Share diperoleh skor terbesar yaitu 65\% pada kriteria "aktif", sedangkan pada kelas kontrol yang tidak mengunakan metode Think Pair Share diperoleh skor terbesar yaitu $82 \%$ pada kriteria "cukup aktif".

Rata-rata nilai siswa pada kelas eksperimen yaitu 81,91 dengan kriteria "baik" lebih besar dibanding rata-rata nilai siswa pada kelas kontrol yaitu 65,29 dengan kriteria "cukup", maka dengan demikian siswa dikelas eksperimen yang menggunakan metode think pair share lebih aktif dibanding siswa dikelas kontrol yang tidak menggunakan metode think pair share.

Hal ini disebabkan karena pada kelas eksperimen menggunakan metode think pair share yang mendorong siswa untuk lebih berfikir dan berani untuk mengeluarkan pendapatnya sehingga siswa lebih aktif dalam proses pembelajaran. Metode think pair share merupakan salah satu strategi belajar yang lebih fokus pada siswa sebagai pusat dalam proses pembelajaran. Metode ini lebih merangsang dan memberi peluang kepada siswa untuk belajar berfikir dan mengembangkan potensinya secara optimal.

Dari hasil analisis data hasil belajar siswa dapat dilihat dari regresi adalah $\hat{Y}=65,29+16,62 X$ dengan pengujian hipotesis melalui uji $t$ dan uji $F$ harga adalah signifikan. Uji " $\mathrm{t}$ " diperoleh harga $\mathrm{t}$ hitung $=8,858$ dan $\mathrm{t}$ tabel pada dk 68 pada $\alpha 0,05$ diperoleh $\mathrm{t}$ tabel $=1,997$ dan pada $\alpha$ 0,01 diperoleh $\mathrm{t}$ tabel $=$ 2,654 . Hal ini dibuktikan dengan uji hipotesis t hitung > t tabel $(8,858>$ 1,997). Sedangkan berdasarkan uji " $F$ " diperoleh harga $\mathrm{F}$ hitung $=1,73$ dan F tabel pada dk 33 pada $\alpha 0,05$ diperoleh $\mathrm{F}$ tabel $=1,79$ dan pada $\alpha$ 0,01 diperoleh $\mathrm{F}$ tabel $=7,022$. Hal ini dibuktikan dengan uji hipotesis $\mathrm{F}$ hitung $<\mathrm{F}$ tabel $(1,73<1,79)$. 
Setelah dianalisis dari data penelitian pada pengajaran dengan menggunakan metode think pair share pada kelas eksperimen dan yang tidak menggunakan metode think pair share dimana variabel $\mathrm{X}$ dan variabel $\mathrm{Y}$ didapatkan pada perhitungan koefisien determinasi $\left(\mathrm{r}^{2}\right)$ adalah 0,543 atau 54,3\%. Berarti Ho ditolak dan Ha diterima, dengan kata lain adanya pengaruh metode think pair share terhadap hasil belajar siswa sebesar 54,3\%.

Jadi baik pada pengujian dengan uji " $t$ " maupun uji " $F$ " samasama menunjukkan hasil yang sama yaitu pengaruh positif terhadap hasil belajar siswa dengan menggunakan metode thunk pair share pada mata pelajaran ekonomi materi uang di SMEA Taqwa Belitang OKU Timur.

Dari data penelitian diatas, baik berupa data observasi maupun tes dapat dilihat bahwa ada pengaruh yang sangat kuat dalam proses belajar mengajar dengan menggunakan metode think pair share di kelas X IPS 3 (kelas eksperimen), proses belajar mengajar sangat efektif dan aktif dibanding kelas X IPS 2 (kelas kontrol) yang tidak menggunakan metode think pair share.

Maka dengan menggunakan metode think pair share pada mata pelajaran ekonomi materi uang dikelas kelas $\mathrm{X}$ IPS 2 dapat meningkatkan hasil belajar siswa di SMEA Taqwa Belitang OKU Timur..

\section{KESIMPULAN}

Berdasarkan hasil penelitian yang telah dilakukan mengenai "Pengaruh Metode Think Pair Share Terhadap Hasil Belajar Siswa Pada Mata Pelajaran Ekonomi di SMEA Taqwa Belitang OKU Timur".maka dapat disimpulkan bahwa :

a. Terdapat pengaruh metode Think Pair Share Terhadap Hasil Belajar Siswa Pada Mata Pelajaran Ekonomi di SMEA Taqwa Belitang OKU Timur., berdasarkan perhitungan dengan menggunakan rumus koefisien determinasi $\left(\mathrm{r}^{2}\right)$ adalah 0,543 atau $54,3 \%$. Jadi pengaruh hasil belajar siswa pada mata pelajaran ekonomi yang menggunakan metode Think Pair Share sebesar $54,3 \%$.

b. Berdasarkan hasil tes belajar siswa pada mata pelajaran ekonomi didapat nilai hasil belajar siswa rata-rata pada mata pelajaran ekonomi di kelas X IPS 3 untuk kelas eksperimen adalah 81,91 dengan kriteria baik, sedangkan nilai rata-rata di kelas X IPS 2 untuk kelas kontrol adalah 65,29 dengan kriteria cukup.

c. Berdasarkan data observasi siswa didapat nilai keaktifan belajar siswa rata-rata pada mata pelajaran ekonomi di kelas X IPS 3 untuk kelas eksperimen adalah 84,31 dengan kriteria sangat aktif, sedangkan nilai rata-rata di kelas $\mathrm{X}$ IPS 2 untuk kelas kontrol 
adalah 60,04 dengan kriteria cukup aktif.

\section{Saran}

Dengan adanya pengaruh pembelajaran dengan menggunakan metode Think Pair Share terhadap hasil belajar siswa, maka ada beberapa saran yang dapat peneliti berikan:

a. Bagi guru

Agar proses pembelajaran dengan menggunakan metode Think Pair Share dapat dijadikan salah satu alternatif dalam proses pembelajaran ekonomi untuk lebih mengaktifkan siswa sehingga tujuan pembelajaran akan mudah dicapai.

b. Bagi Siswa

Agar lebih mempersiapkan diri dengan cara mempelajari terlebih dahulu materi yang akan diajarkan sehingga proses belajar akan berlangsung lebih mudah dan dan aktif dalam proses pembelajaran.

c. Bagi Sekolah

Diharapkan dapat memberikan masukan bahan kajian dalam usaha perbaikan proses pembelajaran di sekolah sehingga mutu pendidikan dapat lebih baik.

\section{DAFTAR PUSTAKA}

Arikunto, Suharsimi. (2010). DasarDasar Evaluasi Pendidikan. Jakarta : PT. Bumi Aksara

Huda, Miftahul. (2011). Cooperative Learning Metode, Teknik, Struktur, dan Model Terapan. Yogyakarta: Pustaka Belajar.
Lestari, N. D. (2018). Pengaruh Strategi Pembelajaran Kreatif Produktif Terhadap Motivasi Berwirausaha Mahasiswa di Univsersitas PGRI Palembang. In Prosiding Seminar Nasional Program Pascasarjana Universitas PGRI Palembang, Vol. 5, No. 05 (2018) hal: 177182.

Masnunah. (2018). Penerapan Model Cooperative Learning Tipe Think Pair Share Pada Pembelajaran Menulis Teks Berita Pada Mahasiswa. Wahana Didaktika, Vol. 16 No. 2 (2018) hal: 235-242

Putri, Devi Nur Ahni Oktavia dkk. (2019). Pengaruh Model embelajaran Concept Attainment Terhadap Hasil Belajar Siswa Pada Mata Pelajaran Ekonomi Di Sma Srijaya Negara Palembang. Jurnal Neraca: Jurnal Pendidikan dan Ilmu Ekonomi Akuntansi, Vol. 3 No. 1 (2019) hal: $77-88$

Riduan. (2011). Belajar Mudah Penelitian Untuk Guru Karyawan dan Peneliti Pemula. Bandung : Alfabeta Sudjana, Nana. (2010). Penilaian Hasil Proses Belajar Mengajar. Bandung : PT Remaja Rosdakarya Offset.

Sugiyono. (2010.) Metode Penelitian Pendidikan (Pendekatan Kuntitatif, Kualitatif, dan $R \& D)$. Bandung : Alfabeta.

Yulaini, Erma dkk. (2020). Perbedaan Hasil Pembelajaran Ekonomi dengan Menggunakan Metode Pembelajaran Time Token dan Think Talk Write. Jurnal 
PROFIT: Kajian Pendidikan Ekonomi dan Ilmu Ekonomi, Vol. 7 No. 1, (2020) hal 1-12 DOI:https://doi.org/10.36706/j p.v7i1.11216 